\title{
ЦИФРОВІ ТЕХНОЛОГІЇ В ПРОЦЕСІ НАВЧАННЯ ОСІБ 3 ПОРУШЕННЯМИ ЗОРУ
}

\author{
Лілія Потапюк \\ кандидат педагогічних наук, доцент, \\ доцент кафедри соціогуманітарних технологій, \\ Луцький національний технічний університет \\ м. Луцьк, Україна \\ ORCID ID 0000-0003-0830-8758 \\ potapiuk2020@gmail.com \\ Оксана Димарчук \\ вчитель інформатики О3 «Вишнівський ліцей» \\ c. Вишнів, Україна \\ ORCID ID 0000-0002-3461-8250 \\ ksushadymar.1998@gmail.com
}

\begin{abstract}
Анотація. Необхідною умовою надання якісної освіти особам з особливими освітніми потребами є усунення перешкод до навчання і організація освітнього процесу з урахуванням індивідуальних потреб учнів. Створення сприятливих умов навчання для таких учнів може бути досягнуто на основі використання відповідних методів в навчальному процесі, а також забезпечення доступності інформаційних ресурсів і технологій. У статті зосереджена увага на основних особливостях та шляхах використання інформаційно-комунікаційних технологій в інклюзивній освіті, а також зосереджено увагу на основні принципи навчання дітей 3 порушеннями зору. Проаналізовано вплив цифрових технологій на розвиток дітей 3 порушеннями зору, представлено перелік технологій, що використовуються для навчання дітей $з$ порушеннями зору. Виділено методичні цілі використання програмних засобів в організації освітнього процесу.
\end{abstract}

Ключові слова: інклюзивна освіта; цифрові технології; інформаційно-комунікаційні технології; програмне та апаратне забезпечення; особи з порушеннями зору.

Постановка проблеми в загальному вигляді. Порушення зору в усіх його проявах негативно впливає на провідний канал інформації про оточуючий світ. Адже 80\% інформації про навколишнє середовище людина отримує саме через зір, а зниження здатності бачити призводить до труднощів у навчальній та комунікативній діяльності.

Щороку в Україні та інших державах народжуються діти з порушеннями зору, а також чимало людей частково або повністю втрачають зір протягом життя внаслідок травм на виробництві чи нещасних випадків. Порушення у діяльності зорового аналізатора викликають труднощі у пізнавальній діяльності, обмежують ii можливості. Таким чином, дитина з порушеннями зору отримує

Професіоналізм педагога: теоретичні й методичні аспекти. Методичні матеріали до проєкту «Цифровий освітній простір: українсько-польський досвід». - Слов’янськ, 2021. 
менше інформації про довкілля (як в кількісному, так і в якісному відношенні), ніж діти 3 хорошим зором.

Зрозуміло, що діти з порушеннями зору потребують особливих умов для повноцінного всебічного розвитку. Спеціальні дошкільні заклади та групи для дітей з порушеннями зору мають на меті не тільки виховання і лікування, а також можливе відновлення і розвиток порушених функцій зору у дітей та підготовку їх до навчання в школі.

Хоча, за статистикою, рівень захворюваності дітей з порушеннями зору, порівняно з 2014 роком понижується, проблема навчання осіб з порушеннями зору залишається відкритою. Кожна група дітей 3 особливими освітніми потребами має свої особливі потреби, які повинен допомагати вирішувати педагог. Освітній процес таких учнів має чимало відмінностей, але використання цифрових технологій допоможе вчителям стати ближче до таких дітей за рахунок більш зручної обстановки на уроці. Пріоритетні потреби дітей з ООП базові (основні) потреби людини. Вони мають потребу в їжі, любові, захисті, освіті.

Варто зазначити, що цифрові (комп'ютерні) технології - це технології, які розв'язують різноманітні дидактичні засоби з використанням комп'ютера, його програмного забезпечення та мультимедійними засобами. Комп'ютер може бути не тільки ефективним інструментом, але і відігравати роль незмінного помічника в процесі навчання та виховання.

Аналіз останніх досліджень і публікацій. Проблемі використання цифрових технологій в інклюзивній освіті присвячено багато наукових праць як українських, так і зарубіжних дослідників. Так, зокрема, Л. Борисенко, В. Березан, Т. Бондаренко, I. Вербицька, Г. Денисова, Ю. Запорожченко, T. Мотуз, Г. Швачич, І. Хомишин, С. Чеб, та ін. аналізували особливості використання інформаційно-комунікаційних технологій в інклюзивній освіті.

Інформаційні системи як засіб підвищення ефективності засвоєння навчального матеріалу учнями 3 порушеннями зору розглядаються в наукових працях Т. Бурнатової， С. Захарова，О.Лозицького， О. Легкого， І. Нікітіної, С. Нетьосова, Т. Попової, Ю. Тулашвілі, Т. Костенко та ін.

Проблему використання асистивних технологій під час організації освітнього процесу для осіб з вадами зору розглядали у своїх наукових доробках Т. Бондаренко, О. Димарчук, Д. Димитриченко, К. Косова, О. Майданчик, Ю. Носенко, Т. Постоян, Л. Потапюк, М. Шишкіна, В. Шведов,Ю.Юрасова, О. Яковенко та інші дослідники.

Проблему ефективності використання асистивних технологій в процесі навчання осіб з порушеннями зору висвітлено зарубіжними вченими I. Eligi 
(2017), F. Silman (2017), S. J. Cranmer (2017), E. Pacheco (2018). На підставі результатів досліджень можна зробити висновок, що учні 3 вадами зору стикаються 3 обмеженнями у доступі та використанні засобів IКТ для підвищення якості їх навчання. Як показують результати дослідження, існує потреба продовжувати не лише надання можливостей навчання для учнів 3 вадами зору, а також надання допомоги по використанню технологій, які додають цінностей їх навчальній діяльності.

Формулювання цілей статті (постановка завдання). Мета статті полягає в обгрунтуванні актуальності та ефективності застосування цифрових (інформаційно-комунікаційних технологій) в процесі навчання учнів 3 порушеннями зору.

Результати дослідження. Інформаційні та комунікаційні технології $є$ одними 3 рушійних сил глобалізації, адже саме вони об'єднують людей i приносять нові інструменти для розвитку. В галузі освіти, широке впровадження нових цифрових технологій представляє великі можливості і ініціює нові педагогічні підходи. Таке бачення розвитку інформаційного суспільства передбачає застосування нових педагогічних технологій і відповідних методів навчання. У зв'язку з цим, інформаційні та комунікаційні технології (ІКТ) стали найбільш придатними інструментами, які можуть допомогти людям з різними вимогами навчання здійснювати своє право на освіту, зайнятість, соціальне життя і відпочинок, а також доступ до інформації. Використання цифрових технологій в сфері освіти повинні посилити незалежність, інтеграцію, і рівні можливості для всіх людей (Міркарімова, 2015).

Ю. Запорожченко (2013) зазначає, що головними умовами для впровадження ефективного використання інформаційно-комунікаційних технологій (рис.1) є підготовка вчителів (педагогів) до використання ІКТ, модифікація компонентів навчального плану та створення належної інфраструктури IКТ.

Цифрові технології можуть використовуватися в різних сферах спеціальної освіти: специфічних і неспецифічних, традиційних та інноваційних. Що стосується кожної сфери, то повинна бути обгрунтована необхідність включення комп'ютерних технологій в процес розвиваючих і корекційних занять для дітей 3 певними порушеннями в розвитку, визначені їх функції та місце в цілісній системі педагогічної роботи. Для цього аналізуються об'єкти пізнання дітей в даній предметній області, розвиваючі та корекційні завдання, зміст і форми продуктивної діяльності, необхідні для їх освоєння. Такого роду аналіз дозволяє зрозуміти, якими функціональними можливостями повинні володіти засоби «Цифровий освітній простір: українсько-польський досвід». - Слов'янськ, 2021. 
навчання. 3 цих позицій оцінюється, наскільки необхідно доповнювати традиційні засоби інформаційними технологіями, а якщо необхідно, то які функції їм пропонуються і яке місце вони повинні займати в рішенні розвиваючих і корекційних завдань навчання дітей в даній предметній області.

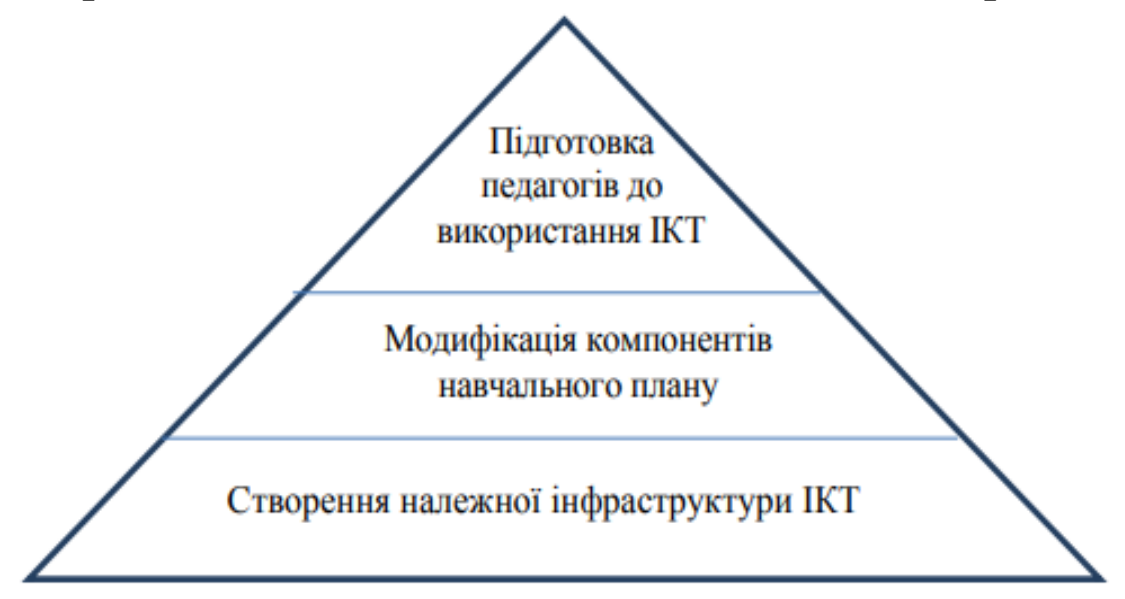

Рис. 1. Головні умови для реалізації інклюзивної освіти з використанням IКТ

Л. Борисенко (2016) виділяє наступні шляхи використання інформаційних технологій:

1. Компенсаційні - це використання спеціальних допоміжних (асистивних) засобів, що забезпечують доступність освітнього процесу для дітей з особливими освітніми потребами;

2. Дидактичні - використання цифрових технологій для задоволення індивідуальних потреб, допомагають створити спеціальні умови в освітньому середовищі. Серед комплексу дидактичних завдань можна виділити проблему розвитку письмового й усного мовлення, а значить, і мислення.

3. Комунікаційні - допоміжні прилади і програмне забезпечення, що допомагають підтримати комунікацію.

Можливість використання ІКТ у дидактичних цілях зумовило потребу перегляду традиційних підходів до навчання, започаткувавши нову віху в освітніх перетвореннях. Інноваційні технології принесли різноманіття педагогічних стратегій для навчання дітей з особливими потребами, ставши реальним інструментом упровадження інклюзивної освіти. Для сприяння особистісному розвитку освітні ініціативи в рамках інклюзивного підходу 3 використанням ІКТ повинні бути спрямовані на задоволення індивідуальних потреб, розкриттю індивідуальних здібностей, розвитку прийнятних для кожного учня індивідуальних ефективних освітніх стратегій. Обізнаність щодо різних видів засобів ІКТ, способів і шляхів їх використання відкриває нові перспективи як для учнів з особливими потребами, так і для педагогів. Для ефективного впровадження ІКТ в інклюзивну освіту необхідно забезпечити 
належний рівень ІК-компетентності педагогічних працівників, їх готовності до розроблення інноваційних методів навчання, оновлення існуючих підходів для реалізації концепції інклюзивної освіти 3 використанням IКТ, що вимагає подальших грунтовних наукових розвідок.

Для вирішення проблем в сфері освіти у дітей з порушеннями зору впроваджуються інформаційно-комунікативні технології, що сприяють їх повноцінному розвитку i соціальній адаптації. Сучасні інформаційнокомунікаційні технології надають для навчання принципово нові можливості. Вони можуть використовуватися на всіх етапах навчання: при поясненні нового матеріалу, при контролі знань, при закріпленні, при узагальненні та систематизації матеріалу. Комп’ютерні технології, доступні для використання в навчальному закладі, умовно поділяють на 3 основні групи: IКТ - лікувальнопрофілактичні; ІКТ - корекційно-розвиваючі; ІКТ - навчальні презентації.

Освітня складова повинна бути спрямована на корекцію відхилень у розвитку, відновлення залишкових функцій зору, оздоровлення дітей, розвиток всіх компенсуючих систем (слух, дотик, мобільність і орієнтування в просторі), формування навичок самообслуговування.

Навчання дітей 3 порушеннями зору спирається на наступні основні принципи:

- широке застосування наочності, що є адаптована до умов сприйняття;

- використання оптичних засобів корекції зорового сприйняття;

- проведення спеціальної роботи для ознайомлення 3 навколишнім світом (екскурсії, спостереження) при регулюючої ролі мови як засобу компенсації сліпоти;

- розвиток предметно-практичних дій на основі поетапного, виконання завдань (ручна праця, конструювання, ліплення, аплікація та ін.);

- організація наступності між навчанням в дитячому саду і школахінтернатах для дітей 3 порушеннями зору, між громадським і сімейним вихованням;

- створення оптимальних умов для зорового сприйняття (достатня освітленість, доступне розташування наочного матеріалу, регулювання зорових навантажень, організація корекційних вправ для зору).

I. Роберт (2019) в освітньому процесі виділяє такі методичні цілі використання програмних засобів:

- індивідуалізація і диференціація процесу навчання;

- здійснення самоконтролю і самокорекції навчальної діяльності;

- візуалізація навчальної інформації; «Цифровий освітній простір: українсько-польський досвід». - Слов’янськ, 2021. 
- моделювання та імітація досліджуваних процесів або явищ;

- здійснення контролю $з$ діагностикою помилок і зі зворотним зв'язком;

- формування уміння приймати оптимальне рішення в різних ситуаціях;

- розвиток певного виду мислення;

- посилення мотивації навчання;

- формування культури пізнавальної діяльності та ін.

Цифрові технології, які надають потенційну допомогу в навчанні i розвитку дітей з особливими потребами, також $є$ представниками сучасних «асистивних інформаційних технологій». Вони можуть бути i у вигляді апаратно-технічного (або спеціального) пристрою або програмного забезпечення для цифрових пристроїв, включаючи сучасні мобільні технології (смартфони, планшети та інші).

До апаратно-технічних або спеціальних пристроїв із вбудованими програмними забезпеченнями можна віднести:

та інші;

- стаціонарні персональні комп’ютери, ноутбуки, планшети, смартфони

- спеціальні периферійні пристрої (клавіатура Брайля, Принтер Брайля, пристосовані джойстики та інші);

- спеціальні пристрої для людей 3 обмеженими можливостями (акустичні системи для людей 3 порушеннями слуху, смарт-окуляри, смартгодинник для людей з порушеннями зору, різні пристрої з ефектом спалаху для людей з порушеннями слуху та інші).

Вчені у своїх дослідженнях оперують різними термінами стосовно цифрових технологій, досить часто зустрічається поняття і електронних ресурсів. Так, І. Нікітіна (2018), класифікує електронні ресурси в залежності від цілей, функціональних можливостей та його типу (рис. 2).

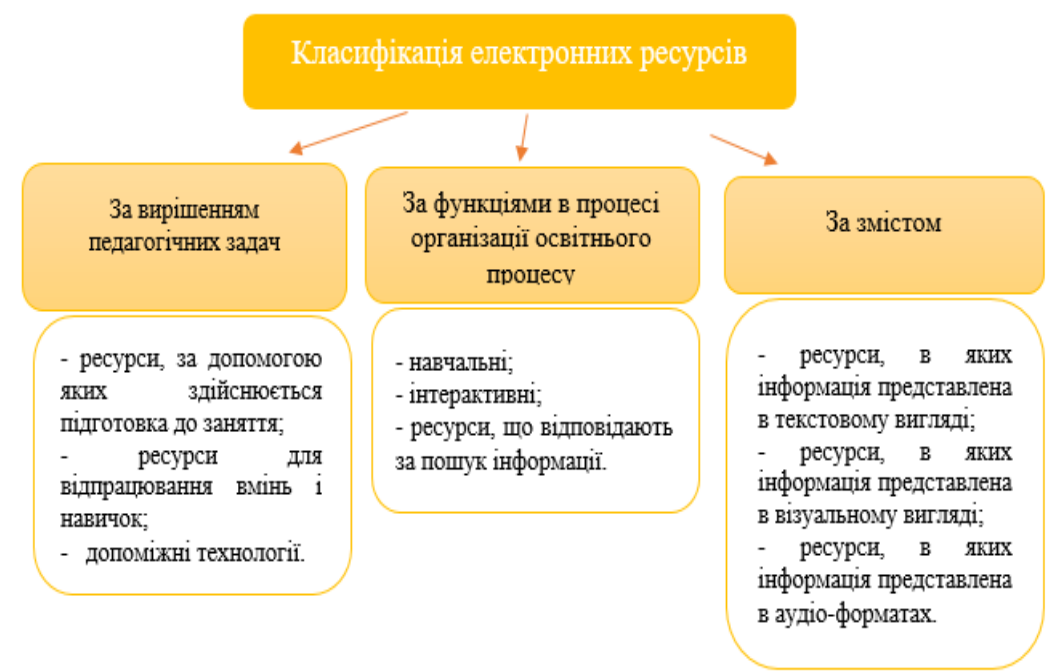

Рис. 2. Класифікація електронних ресурсів 
Пристосування, що роблять навчання легшим, прийнято називати асистивними технологіями. Асистивні технології не несуть за собою мети «вилікувати», ту проблему, яка привела дитину до цього способу навчання, але вони можуть допомогти учневі зробити навчання комфортним та успішним, а також навчити сприймати себе повноцінним членом суспільства. I, що не менш важливо, ці технології не обов'язково повинні бути високотехнологічними.

Т. Мотуз (2021) виділяє такі типи засобів інформаційно-комунікаційних технологій, що використовуються для навчання дітей з особливими освітніми потребами:

- «стандартні технології - наприклад, комп’ютери, що мають вбудовані функції налаштування для осіб з особливими освітніми потребами;

- доступні формати даних, відомі також як альтернативні формати наприклад, доступний HTML, що говорять книги системи DAISY; а також «низько-технологічні» формати (система Брайля);

- допоміжні технології: слухові апарати, пристрої для читання з екрану, клавіатури зі спеціальними можливостями, та ін.»

Для навчання дітей $з$ порушеннями зору використовують: брайлівський дисплей, програми невізуальних доступу до інформації (ScreenReader), синтезатори мови (RHVoice), брайлівські принтери (Embosser), аудіозаписи (DAISY), які читають пристрої (SaraCE), тифло комп'ютери, програми збільшення зображення на екрані комп'ютера (MAGic) та ін. (Потапюк, Димарчук, 2021).

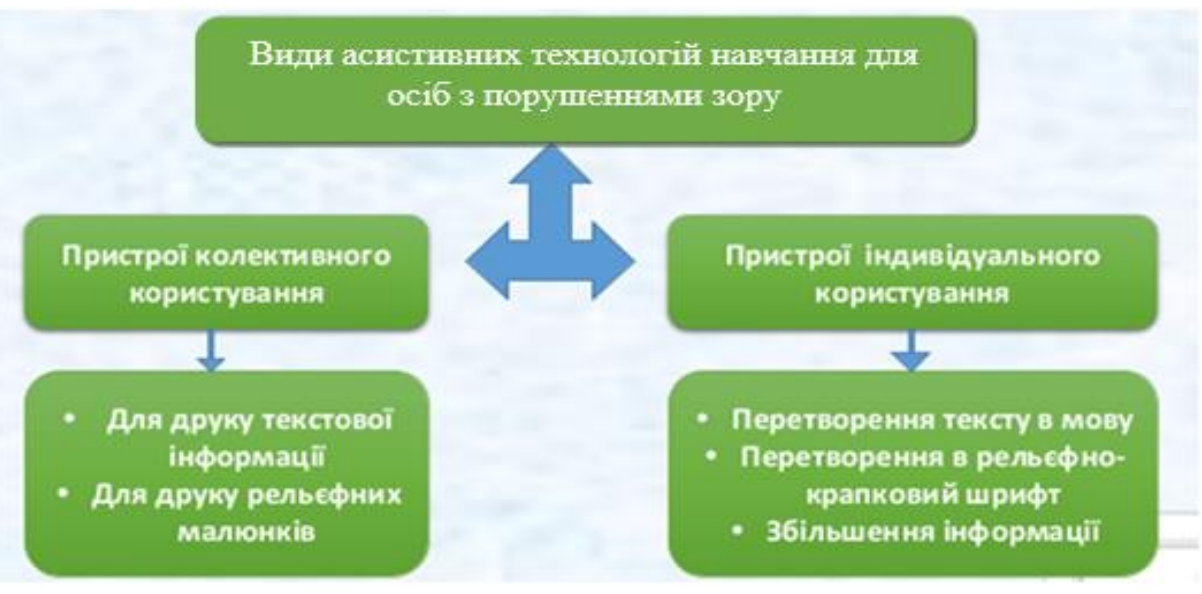

Рис. 3. Види асистивних технологій навчання для осіб з порушеннями зору

Таким чином, можна виділити наступні переваги у використанні інформаційно-комунікаційних технологій при навчанні дітей з порушеннями зору:

- візуалізація наданого навчального матеріалу (скорочення часу на 
трансляцію навчального матеріалу, збільшення обсягу продуктивних видів діяльності, створення цікавих навчальних i дидактичних посібників, роздаткових, оціночних і тестуючих матеріалів);

- подолання наявних і попередження нових відхилень у розвитку (концентрація уваги, розвиток мислення, уяви, дрібної моторики);

- індивідуалізація корекційного навчання (забезпечення кожній дитині адекватного особисто для нього темпу і способу засвоєння знань, надання можливості самостійної продуктивної діяльності);

- підвищення мотивації та активізація пізнавальної діяльності учнів (рішення психолого-педагогічних завдань, підвищення ефективності пізнавальної діяльності).

Перераховані завдання вирішуються за допомогою різних інформаційнокомунікаційних засобів: апаратних (комп'ютер, проектор, фото і відеотехніка, звукозаписні пристрої, мультимедіа і т.д.) і програмних (віртуальні конструктори, тренажери, комплексні навчальні пакети, пошукові системи, інтернет). У сучасних умовах до підручників $\epsilon$ нові вимоги (наявність електронної версії). Отже, електронні навчальні посібники можуть використовуватися у вигляді: презентацій; підручників, робочого зошита; тлумачного словника; довідника з навчальними відеофільмами; тренажера для закріплення нових знань; практичного посібника.

Висновки 3 дослідження і перспективи подальших розвідок у цьому напрямі. Отже, слід зазначити, що використання інформаційно-комунікаційних технологій в освітньому процесі дозволяє: розширити спектр видів навчальної діяльності, удосконалювати існуючі і породжувати нові організаційні форми i методи навчання дітей $з$ порушеннями зору. Процес навчання з використанням сучасних інформаційно-комунікаційних технологій сприяе вирішенню основного завдання корекційного виховання - розвиток індивідуальності вихованця, його здібностей орієнтуватися i адаптуватися у сучасному суспільстві.

Інформаційно-комунікаційні технології підвищують інтерес дітей до навчання, активізують їх пізнавальну діяльність, покращують процес засвоєння матеріалу і сприяють розвитку образного мислення, ставлячи перед дитиною $\mathrm{i}$ допомагаючи йому вирішувати пізнавальні та творчі завдання, акцентуючи увагу на наочності і основному виді діяльності.

Сьогодні, інформаційно-комунікаційні технології мають великий потенціал, адже саме вони забезпечують доступність інформації для людей 3 освітніми потребами. Вдале використання інформаційних технологій в системі спеціальної освіти залежить від наданого нормативного i законодавчого 
середовища і усунення бар'єрів та обмежень. Тільки в такому випадку, якщо всі вище перераховані умови будуть виконані, суспільство зможе реалізувати свій потенціал, а також досягти кінцевої мети, яка полягає в розширенні прав i можливостей, шляхом забезпечення доступності освіти для всіх громадян. Для того, щоб діти з особливими освітніми потребами могли повноцінно приймати участь в освітньому процесі на основі IКТ, необхідно ретельно проаналізувати потреби учнів та дати їм рекомендації про те, які саме технології необхідно використовувати, щоб задовольнити їхні освітні потреби.

\title{
СПИСОК ВИКОРИСТАНИХ ДЖЕРЕЛ
}

1. Pacheco, E., Lips, M., \& Yoong, P. (2018). Transition 2.0: Digital Technologies, Higher Education, and Vision Impairment. The Internet and Higher Education, 37, 1-10.

2. Silman, F., Yaratan, H, \& Karanfiller, T. (2017). Use of Assistive Technology for Teaching-Learning and Administrative Processes for the Visually Impaired People. EURASIA Journal of Mathematics Science and Technology Education, 13 (8), 4805-4813.

3. Eligi, I., \& Mwantimwa, K. (2017). ICT Accessibility and Usability to Support Learning of Visually-Impaired Students in Tanzania. International Journal of Education and Development Using Information and Communication Technology, 13 (2), 87-102.

4. Cranmer, S. J. (2017). Disabled Children and Young People's Uses and Experiences of Digital Technologies for Learning. Retrieved from https://eprints.lancs.ac.uk/id/eprint/88991/4/Disabled_children_final_report_30.11.17.pdf

5. Борисенко, Л. Л. (2016). Впровадження засобів ІКТ в інклюзивну освіту. Система надання освіти дітям з особливими потребами в умовах сучасного навчального закладу: матеріали Всеукраїн. наук.-практ. конф., м. Лисичанськ, 14 грудня 2016 року.). Лисичанськ: ФОП Пронькіна К.В., 26-28.

6. Запорожченко, Ю. Г. (2013). Використання засобів ІКТ для підвищення якості інклюзивної освіти. Інформаційні технології в освіті, 15, 138-145.

7. Миркаримова, Ч. М. (2017). Информационные технологии в образовании. Academy, 6 (21). Взято 3 https://cyberleninka.ru/article/n/informatsionnye-tehnologiiv-inklyuzivnom-obrazovanii.

8. Мотуз, Т., Пасічник, Л., \& Баранець, Я. (2021). Інформаційно-комунікаційні технології в інклюзивному середовищі закладу освіти. Збірник наукових праць Уманського державного педагогічного університету, 2, 172-181.

9. Никитина, И. В. (2018). Электронные образовательные ресурсы для дистаниионного изучения географии в 7-х классах обучающимися с нарушением зрения. Красноярск: СФУ.

10. Потапюк, Л. М., \& Димарчук, О.В.(2021). Асистивні технології як допоміжні засоби організації навчання осіб з вадами зору. Інженерні та освітні технологіï, 9 (1), 8-18.

11. Роберт, И. В. (б. д.). Информатизация образования как новая область педагогического знания. Портал информатизащии образования. Взято 3 http://portalsga.ru/data/2812.pdf.

\section{DIGITAL TECHNOLOGIES IN THE PROCESS OF TRAINING PEOPLE WITH VISUAL DISABILITIES}

\author{
Liliia Potapiuk \\ Candidate of Pedagogical Sciences, Associate Professor,
}

Професіоналізм педагога: теоретичні й методичні аспекти. Методичні матеріали до проєкту «Цифровий освітній простір: українсько-польський досвід». - Слов’янськ, 2021. 
Л. ПОТАПЮК, О. ДИМАРЧУК

Цифрові технології в процесі навчання осіб з порушеннями зору

Associate Professor of Socio-Humanitarian Technologies,
Lutsk National Technical University,
Lutsk, Volyn Region, Ukraine
ORCID ID 0000-0003-0830-8758
potapiuk2020@ gmail.com

Oksana Dymarchuk

Computer Science teacher, Vyshnivsky Lyceum, Vyshniv, Ukraine

ORCID ID 0000-0002-3461-8250

ksushadymar.1998@gmail.com

\begin{abstract}
A necessary condition for providing quality education to people with special educational needs is elimination barriers to learning and the organization of the educational process taking into account the individual needs of students. Creating favorable learning conditions for such students can be implemented through the use of appropriate methods in the learning process as well ensuring the availability of information resources and technologies.

The purpose of the article was to substantiate the relevance and effectiveness of the application digital (information and communication technologies) in the process of teaching students visual impairment. Based on this goal, the focus is on features of the use of information and communication technologies in inclusive educational environment.

Information and communication technologies have become the most suitable tools that can help people with different learning requirements to exercise their right to education, employment, social life and leisure, and access to information. The use of digital technologies in education should be strengthened independence, integration, and equal opportunities for all people. The main ways the use of digital technologies in an inclusive environment are: compensatory, didactic and communication. The principles of training people with visual impairments are possible include: the use of visual aids and optical means of correction of visual perception; conducting special work to get acquainted with the world around (excursions, observation) and the development of subjectpractical actions on the basis of step-by-step implementation tasks; organization of continuity between education in kindergarten and boarding schools for children with visual impairments, between public and family upbringing.

About the main attention should be paid to creating optimal conditions for visual perception (sufficient lighting, accessible location of visual material, visual adjustment loads, organization of corrective exercises for vision). Therefore, it should be noted that the use of information and communication technologies in educational process allows: to expand the range of educational activities, to improve existing and generate new organizational forms and methods of teaching children with visual impairments. Information and communication technologies increase children's interest in learning, activate their cognitive activity, improve the process of learning the material and promote the development of figurative thinking, putting in front of the child and helping her solve cognitive and creative tasks focusing on clarity and basics type of activity.
\end{abstract}

Key words: inclusive education; digital technologies; information communication technologies; software and hardware; visually impaired people.

\title{
REFERENCES
}

1. Pacheco, E., Lips, M., \& Yoong, P. (2018). Transition 2.0: Digital technologies, higher education, and vision impairment. The Internet and Higher Education, 37, 1-10. 
2. Silman, F., Yaratan, H, \& Karanfiller, T. (2017). Use of Assistive Technology for Teaching-Learning and Administrative Processes for the Visually Impaired People. EURASIA Journal of Mathematics Science and Technology Education, 13 (8), 4805-4813.

3. Eligi, I., \& Mwantimwa, K. (2017). ICT Accessibility and Usability to Support Learning of Visually-Impaired Students in Tanzania. International Journal of Education and Development using Information and Communication Technology, 13 (2), 87-102.

4. Cranmer, S. J. (2017). Disabled Children and Young People's Uses and Experiences of Digital Technologies for Learning. Retrieved from https://eprints.lancs.ac.uk/id/eprint/88991/4/Disabled_children_final_report_30.11.17.pdf

5. Borisenko, L.L. (2016). Introduction of ICT Tools in Inclusive Education. The System of Providing Education to Children with Special Needs in a Modern Educational Institution: Proceedings of Ukrainian scientific-practical Conference (Lysychansk, December 14, 2016.). Lysychansk: FOP Pronkina K.V., 26-28.

6. Zaporozhchenko, Yu. G. (2013). Using ICT Tools to Improve the Quality of Inclusive Education. Information Technology in Education, 15, 138-145.

7. Mirkarimova, Ch. M. (2017). Information technology in inclusive education. Academy. 6 (21). Retrieved from https://cyberleninka.ru/article/n/informatsionnye-tehnologii-v-inklyuzivnomobrazovanii.

8. Motuz, T., Pasichnyk, L., \& Baranets, J. (2021). Information and Communication Technologies in an Inclusive Environment of an Educational Institution. Collection of Scientific Works of Uman State Pedagogical University, 2, 172-181.

9. Nikitina, I. V. (2018). Electronic Educational Resources for Distance Learning of Geography in 7th Grade by Students with Visual Impairments. Krasnoyarsk: SFU.

10. Potapyuk, L. M., Dymarchuk, O. V. (2021). Assistive Technologies as Aids to the Organization of Training of People with Visual Impairments. Engineering and educational technologies, 9 (1), 8-18.

11. Robert, I. V. (n. d.). Informatization of Education as a New Area of Pedagogical Knowledge. Portal of Informatization of Education. Retrieved from http://portalsga.ru/data/2812.pdf.

Матеріали надійшли до редакції 01.10.2021 p.

Професіоналізм педагога: теоретичні й методичні аспекти. Методичні матеріали до проєкту «Цифровий освітній простір: українсько-польський досвід». - Слов’янськ, 2021. 